\title{
The State and Society in Conflict Resolution in Indonesia \\ (Conflict Area of West Kalimantan and Central Kalimantan) ${ }^{1}$
}

\author{
Heru Cahyono \\ Center for Political Studies \\ Indonesian Institute of Sciences
}

\section{Introduction}

Several bloody communal conflicts shook some areas in Indonesia from the late 1990s to early 2000s, including widespread violent conflicts in West and Central Kalimantan. ${ }^{2}$ Two groups, the Dayaks and the Malays, both asserting their status as indigenous ethnic groups, fought another ethnic group, migrants from Madura (the Madurese). ${ }^{3}$

The disturbances began in late February 2001 in Central Kalimantan. Thousands of Dayaks attacked the Madurese. There was violence and killing in almost all villages. The disturbances began in Sampit City and spread to Kuala Kapuas, Pangkalan Bun and Palangka Raya. More than 400 Madurese died and 80000 people were forced to leave Kalimantan (Cahyono 2004: 47-48).

1 This summary is based on a research report by P2P-LIPI. The research was conducted by Heru Cahyono, Asvi Warman Adam, Mardyanto Wahyu Tryatmoko and Septi Satriani.

2 These conflicts involved thousands of people and caused a great many to become refugees, hundreds to die and hundreds of houses to be razed.

3 The ethnic categories in this society cannot be exact because in both areas there are many Madurese who can be categorised as 'indigenous people'; they were born and and have lived for decades in Kalimantan. 
Two years before, in February 1999, a similar disturbance erupted in West Kalimantan in the Sambas district. In this conflict, the Dayaks helped the Malays to fight the Madurese. An official record has noted that 200 people died in this bloody conflict.

Although there are similarities from the point of view of the form of the violence, there are differences in the characteristics and sources of conflict in both periods of hostility. ${ }^{4}$ Ethnic conflict in West Kalimantanparticularly between the Dayaks and the Madurese - has a long history and has been going on for several decades. Since the 1950s, disputes between the Madurese and the Dayaks have continued and there have been thousands of people killed on both sides. Historically, it is a different situation in Central Kalimantan: there, there have been few violent conflicts. There were good social relations between migrants and indigenous people, even though these became strained because of the Dayaks' economic hardship. The history of good relations was why many people were shocked, and questioned how the disturbances in Sampit increased to the point where hundreds of people died.

One of the analytical problems of this research was find the sources of conflict. Conflicts often spread because of a failure to stop the violence. In some cases, there have been indications that the state intentionally let the conflicts worsen. This research paper analyses the efforts by the state and society to resolve conflicts in the short and the long term in West and Central Kalimantan.

Conflict resolution is an attempt to resolve the causes of conflict and further to build new and lasting relations between conflicting parties. What is needed here is not only visionary leadership but also determination by all components of society to halt or prevent the conflict. What is needed is a willingness to forgive, to understand, to

4 Another similarity is the lack of a dominant culture in both areas. Most inhabitants of Central Kalimantan are ethnic Dayaks (1.3 million or 41 per cent of the population). The Malays with 1.2 million make up 39.57 per cent, there are Chinese (11.33 per cent); Bugis ( 5 per cent); Javanese ( 3 per cent) and Madurese (2.75 per cent). Central Kalimantan's inhabitants are Banjarese (24.20 per cent), Javanese (18.06 per cent), Dayak Ngaju (18.02 per cent), Dayak Sampit (9.57 per cent) and Madurese (3.46 per cent). See Sihbudi and Nurhasim (2001). 
help, to respect the rights of others, to accept differences and for the parties to do their duty to society. ${ }^{5}$ Conflict resolution is a scientific concept that emphasises the need to see the path to peace as an open and democratic process. There are four stages of conflict resolution: conflict de-escalation, negotiation, problem solving and peace building (Kriesberg 1998; Zartman 1985; Mitchell 1981: 17-34).

\section{The Role of Society in Conflict Resolution}

The rejection of the return of the Madurese in Sambas was stronger than in Sampit particularly and in Central Kalimantan generally. The rejection was promoted by the Malay Youth Communication Forum [Forum Komunikasi Pemuda Melayu (FKPM)]. As it increased in influence, FKPM became more dominant, in part because of its extensive networking from the village to provincial level. The FKPM is the biggest constraint for the Madurese returning to Sambas.

In contrast, the Sambas Conflict Victims Foundation [Yayasan Korban Kerusuhan Sambas (YKKS)] has striven to return the Madurese to Sambas. However, it does not have strong networks nor was it able to influence public opinion and government policy. Moreover, they did not have a strong 'patron' in the legislature and failed to sway the inner circle of the district government of West Kalimantan province, which is dominated by the Malays.

The peace situation in Sambas post-conflict has stagnated. As a consequence of the strong resistance of the Sambas Malays to the presence of the Madurese, the conflict resolution process has not moved from negotiation. This was because of the conflict's traumas and the desire for revenge on the part of the Sambas Malays, which indicates a cultural factor that needs to be dealt with. The sentiments remained with the Malays; they tended to generalise that all Madurese were guilty in the previous conflict and that the Madurese culture and customs cause problems for indigenous people.

5 See Rusmin Tumanggor, Jaenal Aripin and Imam Soeyoeti, 'Dinamika Konflik Etnis dan Agama di Lima Wilayah Konflik Indonesia'. http://www.depsos.go.id/ Balitbang. 
Memories of the traumatic conflict and the desire for revenge caused the Sambas Malays to build strong barriers to prevent the Madurese returning to Malay land. The 'Sambas Wall' was supported by the elite and at the grass roots. Malay people who had been harmed by the Madurese were among those who opposed the return of the Madurese to the Sambas region. The elite support came from the Sambas sultanate and the District Legislative Assembly [Dewan Perwakilan Rakyat Daerah (DPRD)], dominated by the Malays. The Malay majority in the DPRD will hinder the making of the District Legislation (Peraturan Daerah/Perda), which supports conflict resolution that is more just for the Madurese in the refugee camp. It is not to be expected that the DPRD will support the return of the Madurese to Sambas. Other parties who rejected the Madurese were those with a vested interest in the land that was left by the Madurese.

There were three groups resisting the return of the Madurese: the Malay Youth Communication Forum, the politicians and those who were interested in the land left by the Madurese. Youth groups and politicians have taken the harder line.

Resistance to the return of he Madurese was strong in Sambas; however, it was a different situation in Sampit particularly and Central Kalimantan generally. In neither region was there strong resistance because Central Kalimantan society is more heterogeneous; it comprises three groups: the Christian Dayaks, the Kaharingan Dayaks and the Muslim Dayaks. The groups that take a hard line are small elite groups and those whose families suffered directly at the hands of the Madurese during the conflicts, or those who simply thought poorly of the Madurese.

Not all the Madurese and the Dayaks were involved in the disturbance. In the conflict de-escalation, there were people who helped others to reduce the number of victims or to ameliorate their plight. Moreover, not all the Madurese had to leave their villages, some were protected by Dayaks. Some Madurese, who have returned to Sampit, are convinced that their wealth, which is temporarily held by their Dayak compatriots, is still safe. This indicates that family bonds and inter-ethnic cooperation is still strong in Central Kalimantan. 
In contrast, this research has found that the push for the return of the Madurese to Central Kalimantan is very strong. In Sampit, there is the Muslim Youth Association for the Defence of the Community [Ikatan Pemuda Muslim Pembela Umat (IPMPU)] — established in 2002_that is supported indirectly by the Muslim members of the East Kotawaringin DPRD. They endorsed the Madurese efforts to return to Sampit. ${ }^{6}$ Another organisation which has striven to allow the return of the Madurese is the Communication Forum of Central Kalimantan Conflict Victims [Forum Komunikasi Korban Kerusuhan Kalteng (FK4)].

In the post-conflict era, people from other ethnic groups felt the loss of the Madurese who had left Central Kalimantan. The uncertainties of the economy and the increase in criminality encouraged some religious leaders in Sampit to help overcome the conflict. The emergence of the IPMPU, pioneered by religious leaders from many ethnic groups, is an important phenomenon in the restoration efforts of Sampit City. The establishment of the IPMPU was a supporting factor in the successful return of the Madurese to Sampit. The IPMPU's presence hindered indirectly the hardline groups in Sampit. The IPMPU was seen as an informal, temporary organisation; however, a closer look shows that this Muslim organisation was supported by the political elite in the East Kotawaringin DPRD at that time, as well as by the Madurese elites. The presence of the Muslim Dayaks, who supported the reintegration process, has shown that Dayaks do not speak as one when they deal with the Madurese in Central Kalimantan.

\section{The Role of the State in Conflict Resolution}

The role of the state in resolving the conflict in Sambas was relatively weak, except at the early stage of conflict de-escalation and it was not very successful. The state intervened for humanitarian reasons; however, its role was limited to dealing with returning refugees and protecting Madurese assets. Nevertheless, the protection of the Madurese land and other assets was not successful because these were controlled by other parties.

6 However, their efforts were hindered when a karaoke bar was burned down in Sampit and this group was accused of being responsible. 
At the de-escalation stage of the conflict, the state played almost no part in the short term; for instance, it did little to control or to prevent a massive and destructive conflict escalation and to stop the violence quickly. In the longer term, the state was not able to fulfil its role in conflict de-escalation. This finding is based on the local situation in Sambas district that has not changed much. At the time, hatred of the Madurese was still strong and was intentionally maintained by the Malay group (grassroots, formal and informal leaders). In the longer term, the state was not able to solve the problems and to ensure justice for the Madurese. Its part in the conflict resolution satisfied one party only, the Sambas Malays.

In the conflict de-escalation stage, the state intervened to stop the killing. It sent in the army to control or stop the conflict, to reduce the number of casualties and to dispense humanitarian aid. Using the army was not successful because the general intervention policies were unclear and because the command structure of the security forces was poorly organised.

The government's humanitarian programs for refugees in both provinces were conducted differently. Refugees from Sambas were placed in other parts of West Kalimantan where there were indications that the programs to help returning refugees; like land procurement and the building of barracks, was hampered by internecine disputes between government agencies and also by poor communication between provincial and district governments. However, after the Sampit disturbance in 2001, refugees who were sent to East Java and Madura have created new problems for local government. That is why the Sampit case has been seen as an inter-province problem compared with Sambas, which was seen as an intra-province problem. It is interesting to note that conflict resolution in Central Kalimantan not only involved local governments in Central Kalimantan and East Java, but also in East and South Kalimantan, which where very active in resolving the conflict between the Dayaks and the Madurese. 


\section{Conclusion and Recommendations}

The prevention of the return of the Madurese to Sambas was organised by the Sambas Youth Communication Forum (Forum Komunikasi Pemuda Sambas) and showed that there was a shift in conflict dynamics from emotion to well-planned action. This activity was supported by networking among elites, bureaucrats and the Sambas Malay society in this district. There was also a political reconfiguration at the local level, which was dominated by the Malay ethnic group. Therefore, politically, Sambas society became homogeneous but Central Kalimantan society more heterogeneous, comprising Christians, Muslims and Kaharingan Dayaks.

When the field research field was done in 2006, conflicts in both regions had finished. In East Kotawaringin district (Sampit) for instance, the Madurese had returned to their land, but in the Sambas district they were still barred. Drawing on the Kriesberg theory that conflict resolution has four stages, it can be concluded that Central Kalimantan society is more developed than West Kalimantan. The Sampit case has entered its third stage, but Sambas is still at the second stage. It is argued that Kriesberg's four stages of conflict resolution are not absolute: one stage does not automatically begin when the previous stage finishes.

Table 1

Comparative Analysis of Conflict Resolution Development in West Kalimantan and Central Kalimantan

\begin{tabular}{|l|l|l|}
\hline & Sambas, West Kalimantan & Sampit, Central Kalimantan \\
\hline 1 & $\bullet \begin{array}{l}200 \text { people died, } \\
\text { Conflict data } 000 \text { refugees. } \\
\text { Refuge location in } \\
\text { West Kalimantan. }\end{array}$ & $\begin{array}{l}\text { 400 people died, } \\
100000 \text { refugees. } \\
\text { Refuge location in East Java. }\end{array}$ \\
\hline $\begin{array}{l}\text { Post-conflict } \\
\text { condition }\end{array}$ & $\begin{array}{l}\text { The Madurese were } \\
\text { refused entry to Sambas. }\end{array}$ & $\begin{array}{l}\text { The Madurese } \\
\text { returned gradually. }\end{array}$ \\
\hline
\end{tabular}




\begin{tabular}{|c|c|c|}
\hline $\begin{array}{l}3 \\
\text { State role }\end{array}$ & $\begin{array}{l}\text { De-escalation stage } \\
\text { - Security forces did not } \\
\text { act quickly to prevent } \\
\text { conflict escalation. } \\
\text { Humanitarian intervention stage } \\
\text { - Refugees placement became } \\
\text { a project of West Kalimantan } \\
\text { province. Sambas district } \\
\text { was not involved. } \\
\\
\text { Political negotiation stage } \\
\text { Did not run well. Only small } \\
\text { negotiations run by provincial } \\
\text { government and local police. }\end{array}$ & $\begin{array}{l}\text { De-escalation stage } \\
\text { - Security forces did not } \\
\text { act quickly to prevent } \\
\text { conflict escalation. } \\
\text { Humanitarian intervention stage } \\
\text { - } \quad \text { Most of refugees were } \\
\text { placed in East Java. } \\
\text { - Central government prepared } \\
\text { sea transport (Pelni and TNI- } \\
\text { AL) to evacuate refugees. } \\
\text { Political negotiation stage } \\
\text { National support through } \\
\text { meetings in Jakarta, Yog- } \\
\text { yakarta, Malang, Bangkalan. } \\
\text { Elite's interest because } \\
\text { the refugees have } \\
\text { supporters in East Java. } \\
\text { East Java local government } \\
\text { hesitated to accept } \\
\text { Sampit refugees. }\end{array}$ \\
\hline $\begin{array}{l}4 \\
\text { Society role }\end{array}$ & $\begin{array}{l}\text { One group (FKPM), which } \\
\text { refused to cooperate in } \\
\text { conflict resolution, had } \\
\text { very strong connections to } \\
\text { formal elites (bureaucrats, } \\
\text { DPRD) at provincial and } \\
\text { district level and to the } \\
\text { informal elite (Sambas } \\
\text { sultanate) and also strong } \\
\text { support in Sambas society. } \\
\text { Groups that supported } \\
\text { conflict resolution did not } \\
\text { have strong networks. They } \\
\text { only had strong connections } \\
\text { with the Madurese refugees. } \\
\text { NGO role: partial and } \\
\text { there was project rivalry. } \\
\text { The returning refugees are } \\
\text { concentrated in cities. }\end{array}$ & $\begin{array}{l}\text { There was almost no } \\
\text { group that refused conflict } \\
\text { resolution. There were hard- } \\
\text { line groups only among } \\
\text { several Christian Dayak } \\
\text { elites. There are hardliners } \\
\text { at the grassroots, those who } \\
\text { had family members killed } \\
\text { or had had bad experiences } \\
\text { with the Madurese. } \\
\text { Groups that supported conflict } \\
\text { resolution: FK4 played } \\
\text { significant role. Religious } \\
\text { institutions (FPMPU) also } \\
\text { played important roles } \\
\text { supported by the Madurese } \\
\text { and the Dayak Muslims. } \\
\text { NGO role: good cooperation. } \\
\text { Returning refugees are } \\
\text { concentrated in villages. }\end{array}$ \\
\hline
\end{tabular}




\begin{tabular}{|c|c|c|}
\hline $\begin{array}{l}5 \\
\text { The dynamic } \\
\text { relations of } \\
\text { society and } \\
\text { state }\end{array}$ & $\begin{array}{l}\text { Post-conflict: district scope. } \\
\text { Political power became } \\
\text { homogeneous: } \\
\text { (i) building of 'Sambas Wall', } \\
\text { and } \\
\text { (ii) sultanate became } \\
\text { strongly resistant to the } \\
\text { return of the Madurese. } \\
\text { The development of the } \\
\text { region: the elite's and } \\
\text { society's interest were } \\
\text { accommodated and there was } \\
\text { an equitable division of inter } \\
\text { ethnic spheres of power. }\end{array}$ & $\begin{array}{l}\text { Post-conflict: } \\
\text { provincial scope. } \\
\text { (i) Political powers are still } \\
\text { heterogeneous; and } \\
\text { (ii) local leaders [demang] } \\
\text { have roles in organising the } \\
\text { return of the Madurese. } \\
\text { The development of regions: } \\
\text { many elites were included } \\
\text { in government structures. } \\
\text { Development issues caused } \\
\text { Dayak society to refuse to } \\
\text { let the Madurese return. }\end{array}$ \\
\hline
\end{tabular}

\section{References}

\section{Books and Journals}

Avruch, Kevin. 2000. Culture and Conflict Resolution. Washington DC: United States Institute of Peace.

Burton, John. 1990. Conflict: Resolution and Prevention. New York: The Macmillan Press Ltd.

Cahyono, Heru. 2004. 'Konflik di Kalbar dan Kalteng: Sebuah Perbandingan.' Masyarakat Indonesia. Vol. XXX. No.2.

Colombijn and Lindblad (eds). 2002. Roots of Violence in Indonesia. Leiden: KITLV Press.

Effendy, Chairil. 'Militer dan Konflik Sosial di Kalbar'. Paper presented at a seminar held by Center for Regional Development Studies [Pusat Studi Pengembangan Kawasan], University of Tanjungpura, Pontianak.

Jabri, Viviene. 1996. Discourse on Violence: Conflict Analysis Reconsidered. Manchester: Manchester University Press.

Kriesberg, Louise. 2003. Constructive Conflicts from Escalation to Resolution. Maryland: Rowman and Littlefield Publishers Inc.

Marzali, Amri. 2000. 'Perbedaan Etnis dalam Konflik: Sebuah Analisis Sosio Ekonomi terhadap Kekerasan di Kalimantan', in Konflik Komunal di Indonesia. Jakarta: Indonesian-Netherlands Cooperation in Islamic Studies (INIS) and Center for Language and Culture, State Islamic University Syarif Hidayatullah.

Miall, Hugh (et al.). 2000. Resolusi Damai Konflik Kontemporer: Menyelesaikan, Mencegah, Mengelola dan Mengubah Konlik Bersumber Politik, Sosial, Agama dan Ras. terj. Jakarta: PT Raja Grafindo Persada. 
Migdal, Joel S. 1988. Strong Societies and Weak States. New Jersey: Princeton University Press.

Munir. 2001. 'Indonesia, violence and the integration problem,' in Wessel \& Wimhoefer (eds). Violence in Indonesia. Hamburg: Abera.

Purwana, Bambang Hendarta Suta. 2003. Konflik Antarkomunitas di Sambas 1999: Suatu Tinjauan Budaya. Pontianak: Romeo Grafika.

Riwut, Tjilik. 1993. Kalimantan Membangun Alam dan Kebudayaan. Yogyakarta: Tiara Wacana.

Sihbudi, Riza and Moch. Nurhasim (eds). 2001. Kerusuhan Sosial di Indonesia. Jakarta: Grasindo.

Sudagung, Hendro Suroyo. 2001. Mengurai Pertikaian Etnis: Migrasi Swakarsa Etnis Madura ke Kalimantan Barat. Jakarta: ISAI.

Rothman, J. 1992. From Confrontation to Cooperation: Resolving Ethnic and Regional Conflict. Newbury Park, CA: Sage.

Tim Peneliti Universitas Tanjungpura. 2000. Konflik Sosial di Kalimantan Barat: Perilaku Kekerasan Antar-Etnik Dayak-Madura dan Melayu-Madura. Pontianak: Universitas Tanjungpura.

Trijono, Lambang (ed.). 2004. The Making of Ethnic \& Religious Conflict in Southeast Asia: Cases and Resolutions. CSPS Books.

Wanandi, Jusuf. 2002. 'Indonesia: A Failed State'. The Washington Quarterly. Vol. 25. No. 3.

Widjajanto, Andi. 2000. 'Etika Perang dan Resolusi Konflik'. Global: Jurnal Politik Internasional. Vol.1. No. 6.

Zatman, William I. 1985.Ripe for Resolution: Conflict and Intervention in Africa. New York: Oxford University Press.

\section{Website}

Higazi, Adam. 2001. 'Dilemmas and Definitions in Post-Conflict Rehabilitation.' ECDPM discussion paper, http://www.ecdpm.org.

Tumanggor, Rusmin, Jaenal Aripin and Imam Soeyoeti. 'Dinamika Konflik Etnis dan Agama di Lima Wilayah Konflik Indonesia'. http://www.depsos. go.id/ Balatbang. 